\title{
KARAKTERISTIK PSEUDOMONAS VIRIDIFLAVA: PENYEBAB PENYAKIT BUSUK LUNAK DAN EVALUASI VIRULENSINYA PADA KLON ANGGREK PHALAENOPSIS
}

\author{
Hanudin \& Indijarto Budi Rahardjo \\ Balai Penelitian Tanaman Hias \\ J1. Raya Pacet-Ciherang P. O. Box 8 Pacet - Sindanglaya Cianjur, 43253. \\ E-mail: hanudin_handjar09@yahoo.com
}

\begin{abstract}
Characteristic of Pseudomonas viridiflava: Causal agents of soft rot bacterial disease and evaluation of its virulence on orchid phalaenopsis clones. The objectives of this research were to determine the typical symptoms and isolates chararteristics of Pseudomonas viridiflava as the causal agent of soft rot bacterial disease and to find out orchid Phalaenopsis clones resistant to the disease. The scope of this study included exploration and isolation of the pathogens, pathogenicity, biochemical and LOPAT tests, also screening the Phalaenopsis F1 clones resistant to the pathogen. The results showed that isolates Vd6, Ph-7 and Ph-18 obtained from Vanda (in Bandung Nursery) and Phalaenopsis orchids respectively, in glass house of Indonesian Ornamental Crops Research Institute, were identified as $P$. viridiflava and highly virulent on tested orchid plants. Typical symptoms were soft rots characterized by moist and watery decay of the whole leaves, which were initiated as small water-soaked lesions and enlarged rapidly to the entire leaves. Based on biochemical and LOPAT tests, the causal organisms were fluorescent green colonies in King's B medium, not producing levan compound and arginine hydrolase reaction. Pectinolytic activities on potato and tobacco hypersensibility were also positive. According to evaluation test, $10 \mathrm{~F} 1$ accecions Phalaenopsis clones (VL 231, VL 232, VL 233, and VL 240; M22.213 and M22.223; 599.201, 599.205, 599.215 and 599.243) were resistant to that pathogen.
\end{abstract}

Keywords : orchids, bacterial soft rot, Pseudomonas viridiflava, resistant clones

\begin{abstract}
ABSTRAK
Karakteristik Pseudomonas viridiflava: Penyebab penyakit busuk lunak dan evaluasi virulensinya pada klon anggrek phalaenopsis. Tujuan penelitian ini ialah menginformasikan karakteristik isolat Pseudomonas viridiflava penyebab penyakit busuk lunak (PBL), gejala serangan, dan mendapatkan klon anggrek phalaenopsis yang resisten terhadap patogen tersebut. Ruang lingkup penelitian ini mencakup eksplorasi, isolasi, uji virulensi, biokimia, LOPAT, dan penapisan resistensi klon Phalaenopsis. Dari hasil penelitian diketahui bahwa isolat $\mathrm{Vd}-6, \mathrm{Ph}-7$, dan $\mathrm{Ph}-18$ yang diperoleh dari anggrek Vanda dari nursery di Bandung dan Phalaenopsis dari rumah kaca Balai Penelitian Tanaman Hias diidentifikasi sebagai P. viridiflava. Berdasarkan uji biokimia dan LOPAT, karakteristik isolat $P$. viridiflava menunjukkan warna koloni hijau berpendar pada media King's B, tidak menghidrolisa arginine, dan tidak memproduksi levan. Aktivitas pektinolitik pada umbi kentang dan reaksi hipersensitivitas pada daun tembakau ketiga isolat tersebut masing-masing menunjukan reaksi positif. Karakteristik gejala serangan patogen tersebut mula-mula pada organ yang terserang menampakkan bercak hijau kekuningan, kemudian bercak tersebut berkembang dengan sangat cepat hingga menyebabkan pembusukan jaringan yang terinfeksi (daun). Penapisan virulensi isolat PBL dan resistensi klon Phalaenopsis menghasilkan, isolat Vd-6, Ph-7, dan Ph-18 yang bervirulensi tinggi. Selain itu, 10 klon individu populasi F1 Phalaenopsis menunjukkan reaksi resisten terhadap PBL. Ke-sepuluh klon anggrek tersebut ialah VL 231,VL 232,VL 233, dan VL 240; M22.213, dan M22.223; 599.201, 599.205, 599.215, dan 599.243.
\end{abstract}

Kata kunci : anggrek Phalaenopsis, penyakit busuk lunak, Pseudomonas viridiflava, resistensi klon

\section{PENDAHULUAN}

Penyakit busuk lunak (PBL) merupakan salah satu kendala utama dalam budidaya tanaman anggrek dan tanaman lainnya di Indonesia dan juga di beberapa negara beriklim tropis dan sub tropis di dunia (Chia et al., 2003; Hanudin \& Suhardi, 2002). Di Bogor (Jawa Barat) patogen tersebut dapat menginfeksi hampir $100 \%$ anggrek Oncidium, dan $80 \%$ anggrek Paphiopedilum (Hanudin et al., 2011), sedangkan di D.I Yogyakarta, PBL dapat menginfeksi tanaman anggrek Grammatophylum, Dendrobium, dan Catleya dengan 
intensitas serangan berkisar antara 23.9 dan $41.7 \%$ (Joko et al., 2010).

Pada Agustus 2008 di Florida Selatan (USA), sekitar 50\% anggrek Oncidium "var. Gower Ramsey" telah terinfeksi penyakit ini (Cating \& Palmateer, 2011). Selain pada anggrek, sejak tahun 1999 patogen ini telah ditemukan dan menimbulkan kerusakan yang sangat parah pada tanaman kacang-kacangan (Phaseolus vulgaris), buah kiwi (Actinidia deliciosa), dan selada (Lactuca sativa) di wilayah Spanyol (Gonzalez et al. 2003; Goumans \& Chatzaki 1998). Ayasan et al. (2003) melaporkan bahwa di Turki, PBL telah menginfeksi 10\% tanaman melon (Cucumis melo cv. Nun).

Pada umumnya PBL pada tanaman disebabkan oleh Pectobacterium carotovorum subsp. carotovorum (sinonim Erwinia carotovora subsp. carotovora), $P$. carotovorum subsp. atrosepticum (sinonim E. carotovora subsp. atroseptica), dan Dickeya dadantii (sinonim. E. chrysanthemi) (Samson et al., 2005). Penyakit tersebut dapat pula disebabkan oleh bakteri pseudomonas kelompok pectinolitik seperti Pseudomonas fluorescens, P. marginalis, dan P. viridiflava (Godfrey \& Marshall 2002).

Strain $P$. viridiflava, umumnya dapat dibedakan melalui pengujian secara biokimia, fisiologi, dan aktivitas pectinolitik pada umbi kentang serta reaksi hipersentitivitas pada daun tembakau (Gonzales et al., 2003). Lelliott \& Stead (1987) melaporkan bahwa untuk mengetahui karakteristik dan membedakan isolat bakteri tersebut, dapat dilakukan dengan uji LOPAT $(L=$ levan production; $O=$ Oxidase production; $P=$ Pectinolytic activity; $A=$ Arginine dihydrolase production; and $T=$ Tobacco hypersensibility).

Pengujian aktivitas pectinolitik pada umbi kentang, reaksi hipersensitivitas pada daun tembakau, serta uji patogenisitas pada anggrek Vanda dan Phalaenopsis merupakan serangkaian uji virulensi isolat $P$. viridiflava. Isolat yang bervirulensi tinggi ditunjukkan oleh kemampuannya untuk menimbulkan gejala busuk lunak yang semakin cepat pada seluruh jaringan tanaman yang terinfeksi. Selanjutnya isolat tersebut digunakan untuk menapis beberapa individu F1 klon Phalaenopsis, yang akan digunakan sebagai induk sumber genetik tanaman resisten terhadap PBL.

Pada tahun 2005 - 2008, Balai Penelitian Tanaman Hias (BALITHI) telah melakukan penapisan resistensi terhadap PBL pada klon anggrek Phalaenopsis. Dari penapisan tersebut masing-masing diperoleh individu populasi F1 Phalaenopsis cormucervi nomor P 605 dan P 503; E 2513 dan SK 17; P 157 No.12, 45, dan 71; serta E 2189 No. 64 yang menujukkan reaksi resisten terhadap PBL (Hanudin \& Suhardi, 2009). Pengujian penapisan resistensi terhadap PBL pada klon anggrek Phalaenopsis harus dilakukan secara terus menerus. Hal tersebut dimaksudkan untuk memperoleh sumber genetik yang lebih banyak untuk dipilih, karena klon yang diperoleh belum tentu kompatibel bila digunakan sebagai sumber genetik induk persilangan. Selain itu, penapisan klon anggrek diperlukan untuk menguji virulensi isolat PBL yang telah dikoleksi oleh laboratorium Bakteriologi BALITHI.

Penelitian ini bertujuan untuk memperoleh informasi karakterisik isolat $P$. viridiflava yang bervirulensi tinggi. Karakteristik isolat tersebut meliputi gejala serangan pada tanaman anggrek, dan bentuk, ukuran, serta warna koloni pada berbagai media yang diuji. Selain itu, penelitian ini juga bertujuan untuk mendapatkan individu populasi F1 klon anggrek Phalaenopsis yang resisten terhadap penyakit tersebut.

\section{METODE PENELITIAN}

Eksplorasi dan Isolasi $\boldsymbol{P}$. viridiflava. Eksplorasi sampel tanaman yang diduga terinfeksi $P$. viridiflava dilakukan dengan survey ke "nursery Ridho Orchid" di Lembang-Bandung dan rumah kaca Kebun Percobaan (KP) BALITHI di Segunung dan Cipanas, Cianjur. Sampel daun tanaman terinfeksi, dibawa ke Laboratorium Bakteriologi untuk diisolasi. Sebelum diisolasi, data sampel tanaman dicatat dalam buku koleksi sebagai informasi sumber isolat. Adapun data yang dicatat meliputi nomor isolat, tanaman inang, lokasi, ketinggian tempat (latitude), tanggal isolasi, dan kolektor.

Isolasi patogen dilakukan dengan memotong jaringan daun pada bagian perbatasan yang sehat dan sakit sebesar $\pm 1,5 \mathrm{~cm}$. Jaringan tanaman tersebut dihancurkan hingga halus menggunakan mortal steril, dan ditambahkan dua ml air steril hingga membentuk suspensi. Suspensi tersebut digoreskan pada media King's B (komposisi media KB per liter : 20 g proteose peptone (Difco \# 3), $10 \mathrm{~g}$ glycerol, 1,5 $\mathrm{g} \mathrm{K}_{2} \mathrm{HPO}_{4}, 1,5 \mathrm{~g}$ $\mathrm{MgSO}_{4} .7 \mathrm{H}_{2} \mathrm{O}, 15,0 \mathrm{~g}$ agar dan 11 air steril), kemudian diinkubasikan ke dalam inkubator pada suhu $32 \pm 2{ }^{\circ} \mathrm{C}$ selama 24 jam.

Isolat $P$. viridiflava pada media $\mathrm{KB}$, menunjukkan warna koloni hijau berpendar (fluorescens) bila disinari lampu ultra violet (Lelliott \& Stead, 1987). Koloni bakteri tersebut kemudian diinokulasikan pada potongan umbi kentang segar untuk pengujian degradasi pektat. Umbi kentang yang digunakan untuk pengujian ini ialah yang berbobot minimal $30 \mathrm{~g}$, kemudian dicuci menggunakan air ledeng. Setelah itu, umbi kentang direndam dalam alkohol $70 \%$ selama 5 menit, untuk disterilkan permukaan kulitnya. 
Setelah direndam dalam alkohol, umbi tersebut dikeringkan menggunakan kertas tisu dan dipotong melintang dengan ketebalan 0,5-1,0 cm menggunakan pisau yang disterilkan. Biakan murni yang diduga $P$. viridiflava digoreskan pada potongan umbi kentang tersebut, kemudian dimasukkan ke dalam cawan petri steril yang di dalamnya dilapisi tisu basah sebagai pelembab. Pengamatan terhadap degradasi pektat, dilakukan pada 24 jam setelah inokulasi. Reaksi positif dari uji ini ditunjukkan oleh pembusukan pada umbi kentang yang diinokulasi. Isolat yang menunjukkan reaksi positif pada pengujian ini, diisolasi kembali untuk diuji lanjutan (Postulat Koch, uji biokimia, morfologi, dan uji LOPAT).

Uji Patogenisitas dan Virulensi. Uji patogenisitas (Postulat Koch) dilakukan untuk memastikan bahwa patogen yang diisolasi adalah penyebab penyakit yang sedang dipelajari. Pengujian tersebut meliputi isolasi patogen dari jaringan tanaman yang terinfeksi, purifikasi isolat, uji degradasi pektat pada umbi kentang, inokulasi pada tanaman inang, dan isolasi kembali.

Setelah uji patogenisitas memperoleh isolat yang positif, kemudian dilakukan uji virulensi pada tanaman sehat anggrek Vanda dan Phalaenopsis. Tanaman dipelihara di dalam rumah kaca yang terkontrol, dengan suhu harian berkisar antara $18-30{ }^{\circ} \mathrm{C}$.

Biakan murni bakteri yang diuji disuspensikan dalam $50 \mathrm{ml}$ air steril, kemudian diinokulasikan pada daun anggrek berdasarkan metode pin priking (Hanudin \& Suhardi 2009). Daun anggrek dilukai menggunakan jarum suntik, kemudian kapas ditempelkan (kapas sebelumnya telah dicelupkan ke dalam suspensi bakteri dengan kerapatan $10^{8}$ colony forming unit $(\mathrm{cfu} / \mathrm{ml})$ pada bekas luka (Gambar 1).

Peubah yang diamati meliputi intensitas serangan (IS) penyakit busuk lunak, berdasarkan modifikasi metode Handayati et al.(2004), yaitu berdasarkan rumus IS $=\mathrm{A} / \mathrm{N} \times 100 \%$, dengan IS adalah intensitas serangan busuk lunak, A adalah luas daun yang yang bergejala busuk lunak, dan $\mathrm{N}$ adalah luas daun yang diinokulasi). Pengamatan ini dilakukan setiap hari, dimulai 2 hari

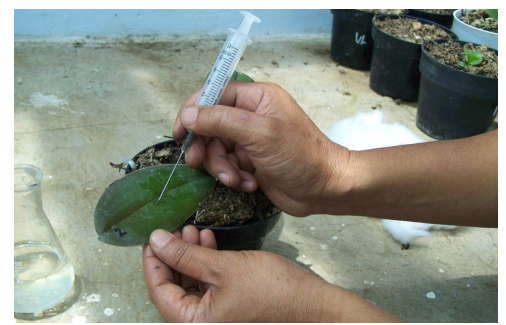

setelah inokulasi (HSI) sampai dengan 5 HSI atau setelah seluruh daun terinfeksi $P$. viridiflava.

Pengujian Morfologi dan Biokimia. Isolat $P$. viridiflava yang digunakan pada pengujian morfologi dan biokimia ini adalah tiga isolat yang menunjukkan reaksi positif pada pengujian patogenisitas dan virulensi. Pengamatan karakteristik morfologi dan biokimia isolat tersebut dilakukan terhadap warna koloni pada media King's B, bentuk sel, kelompok gram, elevasi permukaan, dan tepian koloni yang dilakukan berdasarkan metode Price et al. (1999).

Bentuk sel bakteri yang diduga $P$. viridiflava diamati di Laboratorium Bioteknologi Fakultas Pertanian Universitas Gadjah Mada Yogyakarta dengan menggunakan mikroskop pada pembesarasan $100 \mathrm{x}$. Pengujian biokimia dan fisiologi dilakukan di Laboratorium Bakteriologi BALITHI, berdasarkan metode Lelliott \& Stead (1987).

Pengujian gram dilakukan dengan metode Ryu, yaitu dengan cara meneteskan $10 \mu \mathrm{l}$ larutan $\mathrm{KOH} 3 \%$ pada isolat bakteri di dalam gelas objek lalu digosok menggunakan jarum oose sampai tercampur rata kemudian jarum oose diangkat secara pelan-pelan. Apabila jarum oose diangkat, dan menunjukkan bahwa suspensi bakteri tersebut lengket dan terbentuk benang halus, berarti bakteri tersebut gram negatif atau sebaliknya (Suslow et al., 1982).

Pengujian lainnya yang dilakukan ialah sensitivitas terhadap antibiotik eritromisin yang dilakukan berdasarkan metode Hanudin (1990). Dua ratus ml suspensi bakteri PBL (kerapatan $10^{9} \mathrm{cfu} / \mathrm{ml}$ ), dituangkan ke dalam $75 \mathrm{ml}$ media Nutrient Agar (NA) yang telah dicairkan (suhu $\pm 45{ }^{\circ} \mathrm{C}$ ). Kemudian media tersebut dituang ke dalam cawan petri steril sebanyak $15 \mathrm{ml} /$ cawan petri, didiamkan selama 10 menit hingga media membeku. Setelah media tadi membeku, kertas saring steril berdiameter $0,80 \mathrm{~cm}$ yang sebelumnya telah dicelupkan ke dalam larutan antibiotik eritromisin konsentrasi $35 \mu \mathrm{l} / \mathrm{ml}$ dimasukkan. Biakan bakteri diinkubasi dalam inkubator pada suhu $30+1{ }^{\circ} \mathrm{C}$ selama

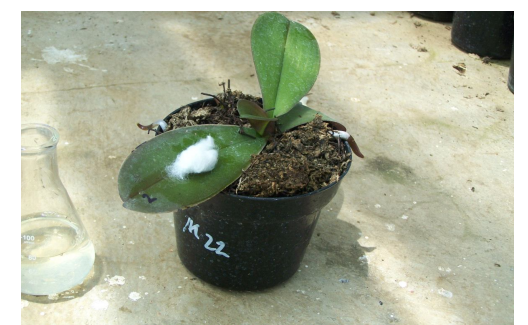

Gambar 1. Metode inokulasi patogen busuk lunak pada anggrek Phalaenopsis secara pin priking. 
48 jam. Pengamatan dilakukan terhadap pertumbuhan bakteri di sekitar kertas saring. Reaksi positif diindikasikan dengan terbentuknya areal hambatan di sekitar kertas saring yang mengandung antibiotik.

Pengujian pertumbuhan isolat pada kondisi suhu ekstrim $\left(34-37{ }^{\circ} \mathrm{C}\right)$, dan tekanan osmotik dalam larutan $5 \% \mathrm{NaCl}$ dilakukan berdasarkan metode Schaad et al. (2001); Lelliott \& Stead (1987). Masing-masing $1 \mathrm{ml}$ suspensi bakteri (kerapatan $10^{9} \mathrm{cfu} / \mathrm{ml}$ ) yang diduga $P$. viridiflava dituangkan ke dalam $10 \mathrm{ml}$ media Nutrient Broth (media NB) di dalam tabung reaksi berkapasitas $50 \mathrm{ml}$. Kultur bakteri tersebut kemudian dimasukkan ke dalam penangas air dengan suhu $34-37{ }^{\circ} \mathrm{C}$, sambil digoyang pada kecepatan $10 \mathrm{rpm}$ dan inkubasi selama 7 hari.

Untuk pengujian pertumbuhan bakteri pada kondisi tekanan osmotik, metodenya hampir sama dengan yang dilakukan pada pengujian suhu ekstrim. Adapun sebagai pembedanya ialah pada komposisi media NB di tambahkan $5 \% \mathrm{NaCl}$, dan suhu inkubasi pada $28 \pm 2{ }^{\circ} \mathrm{C}$ (ditempatkan di ruangan laboratorium/ suhu ruangan). Reaksi positif untuk kedua pengujian ini ditunjukkan oleh perubahan warna media, dari bening menjadi keruh.

Uji LOPAT, merupakan pengujian pembeda antara Genus Pseudomonas yang menyebabkan PBL dan tidak (Lelliott \& Stead 1987). Uji produksi Levan dilakukan pada media NA yang ditambah dengan $5 \%$ sucrose. Isolat PBL yang diuji digoreskan pada media NA, kemudian setelah 24-48 jam diamati bentuk koloni isolat tersebut. Apabila isolat tersebut menunjukkan bentuk koloni yang fluidal, maka isolat tersebut positif memproduksi levan.

Uji oksidase dilakukan dengan cara membiakkan isolat yang diuji pada media NA. Setelah tumbuh (24 jam), isolat tersebut digoreskan pada kertas oxidase detection strips [(ODS) dari Medvet, Australia Cat. No.05034.100865] menggunakan jarum oose yang terbuat dari plastik. Reaksi positif diindikasikan dengan perubahan warna isolat (dari krem menjadi ungu), setelah 10 detik digoreskan pada kertas ODS tersebut.

Uji pektinase dilakukan pada belahan umbi kentang. Adapun prosedur pengujian dan penentuan kriteria pengamatannya sama seperti pada pengujian degradasi pektat yang telah dilakukan pada saat setelah isolasi $P$. viridiflava.

Uji arginine dehydrolase dilakukan untuk mengetahui apakah isolat tersebut mampu menghidrolisa arginine. Prosedur pengujiannya adalah sebagai berikut. Isolat yang diuji dibiakkan pada media arginine. (Komposisi media tersebut per liter: $1 \mathrm{~g}$ neutralized peptone, $5 \mathrm{~g} \mathrm{NaCl}, 0.3 \mathrm{~g} \mathrm{~K}_{2} \mathrm{HPO}_{4}, 10 \mathrm{~g} \mathrm{~L}(+)$ arginine
$\mathrm{HCl}$, 0.01g red phenol dan 3g agar), diaduk dan disterilkan menggunakan autoclave pada suhu $121{ }^{\circ} \mathrm{C}$ selama 15 menit. Kultur isolat pada media tersebut kemudian diinkubasikan selama tiga hari, dan reaksi positif diindikasikan dengan perubahan warna media dari oranye menjadi merah muda (pink).

Uji reaksi hipersensitivitas (HR) pada daun tembakau dilakukan berdasarkan metode Lelliott \& Stead (1987). Biakan bakteri pada media NA berumur 24 jam dibuat suspensi yang berkerapatan $10^{8} \mathrm{cfu} / \mathrm{ml}$. Kemudian suspensi bakteri tersebut disuntikkan menggunakan jarum hypodermic syringe (berdiameter $0.6 \mathrm{~mm}$ ) pada mesophyll yang terletak di antara tulang daun tembakau. HR diamati pada 24 atau 48 jam setelah inokulasi. Reaksi positif ditunjukkan oleh perubahan warna jaringan daun yang diinokulasi, dari hijau berubah menjadi coklat nekrosis, yang diikuti dengan mengeringnya jaringan tersebut.

Evaluasi Resistensi Klon Phalaenopsis terhadap $P$. viridiflava. Tanaman anggrek yang digunakan untuk pengujian resistensi adalah individu populasi F1 klon VL, M22, dan 599 masing-masing 45 asesi dengan nomor mulai dari 201 sampai dengan 245 yang diperoleh dari bagian pemuliaan BALITHI. Tanaman ditempatkan di rumah kaca yang dilindungi paranet $60 \%$, kemudian dipelihara sesuai dengan Standard Operasional Prosedure (SOP) budidaya anggrek.

Inokulum $P$. viridiflava yang digunakan pada percobaan ini ialah isolat $\mathrm{Ph}-7$ yang digoreskan secara aseptis pada media King's B di dalam 1 buah cawan petri. Setelah biakan murni isolat tersebut tumbuh subur, kemudian disuspensikan ke dalam $20 \mathrm{ml} /$ petri aquades steril sebagai sumber inokulum, dan langsung diinokulasikan pada daun anggrek dengan metode pin priking. Inokulum PBL yang diinokulasikan pada daun anggrek, mempunyai kerapatan populasi $5,2 \times 10^{10} \mathrm{cfu} /$ $\mathrm{ml}$, sedangkan perlakuan kontrol menggunakan air steril yang juga diinokulasikan dengan metode yang sama.

Peubah yang diamati meliputi waktu inkubasi (WI) dan intensitas serangan (IS). WI diamati setiap hari, dimulai 2 hari setelah inokulasi (HSI) sampai dengan 5 HSI atau 100\% daun anggrek yang diinokulasi telah menunjukkan gejala busuk lunak. IS diamati dengan metode yang sama seperti pada pengujian virulensi yaitu berdasarkan rumus IS $=\mathrm{A} / \mathrm{N}$ x $100 \%$.

\section{HASIL DAN PEMBAHASAN}

Eksplorasi dan Isolasi $P$. viridiflava. Berdasarkan hasil isolasi pada media King's B dan uji degradasi pektat pada umbi kentang, dari tujuh isolat PBL diperoleh tiga 
isolat yang diduga $P$. viridiflava. Ketiga isolat tersebut diberi nama masing-masing ialah $\mathrm{Vd}-6, \mathrm{Ph}-7$, dan $\mathrm{Ph}-$ 18 (Tabel 1). Isolat Vd-6 diisolasi dari anggrek Vanda yang diperoleh dari nursery "Ridho Orchid" di Cobogo Lembang - Bandung (Jawa Barat), sedangkan isolat Ph7 dan Ph-18 masing-masing diisolasi dari anggrek Phalaenopsis yang diperoleh dari KP BALITHI di Segunung dan Cipanas. Ketiga isolat tersebut kemudian diuji patogenisitasnya berdasarkan Postulat Koch dan virulensinya pada tanaman sehat anggrek Vanda dan Phalaenopsis.

Uji Patogenisitas dan Virulensi. Hasil uji patogenisitas terhadap ketiga isolat yang diduga $P$. viridiflava pada setiap tanaman menunjukkan gejala serangan yang bervariasi. Karakteristik gejala serangan patogen tersebut pada anggrek Phalaenopsis, mula-mula daun yang terinfeksi menampakkan gejala bercak luka hijau kekuningan (water soaked lesions), kemudian luka tersebut berkembang dengan sangat cepat hingga menyebabkan pembusukan jaringan. Gejala serangan patogen tersebut hampir sama seperti pada tanaman melon (Cucumis melo cv. Nun), yaitu busuk lunak pada bagian kotiledonnya (Ayasan et al. 2003). Pada jenis anggrek Vanda, gejala serangan berupa bercak hitam yang menyebar (Gambar 2).

Pada serangan yang sangat parah, dari luka yang membusuk tercium aroma yang menyengat dan tanaman yang terserang mengalami kelayuan dan akhirnya mati.
Hal ini disebabkan oleh bakteri PBL mampu menghasilkan dan mensekresikan secara efisien satu set enzim maupun isoenzim dalam jumlah besar yang mampu mendegradasi kompleksitas polimer dinding sel tanaman, utamanya kelompok enzim pektinase (pektat liase, poligalakturonase, pektin metil esterase). Enzim pektinase yang merupakan faktor utama patogenisitas bakteri PBL digunakan untuk memecah pektin di dalam lamela tengah dan dinding sel tanaman sehingga menyebabkan kematian jaringan, kerusakan, hingga sel menjadi pecah (Barras et al., 1994).

Berdasarkan hasil uji virulensi pada beberapa jenis anggrek terhadap tiga isolat yang diduga $P$. viridivlava tampak bahwa semua isolat yang diuji menunjukkan virulensi yang tinggi (IS $\geq 60 \%$ ), kecuali isolat $\mathrm{Ph}-18$ yang berasal dari Phalaenopsis Cipanas, menunjukkan intensitas serangan yang sedang atau medium (IS berkisar antara 30-59\%) pada anggrek Vanda (Tabel 2).

Pengujian Morfologi dan Biokimia. Hasil pengujian secara morfologi menujukkan bahwa semua sel bakteri yang tumbuh berbentuk batang dengan elevasi permukaan koloni datar, tepian margin koloni rata/ bergelombang, dan termasuk gram negatif (Tabel 3). Dube (1979) melaporkan bahwa dinding sel gram negatif terdiri atas tiga lapisan mukopeptide. Adapun kandungan mukopeptidenya sebanyak 3-12\% dari total berat kering. Mokopeptide adalah senyawa kimia yang tersusun dari unit n-acetyl glucosamine (Nag) dan n-acetyl muramic

Tabel 1 . Sumber isolat yang diduga $P$. viridiflava penyebab pen yakit busuk lunak pada anggrek

\begin{tabular}{cccccl}
\hline $\begin{array}{c}\text { No. } \\
\text { Isolat }\end{array}$ & $\begin{array}{c}\text { Klon Angrek } \\
\text { Inang }\end{array}$ & Lokasi & $\begin{array}{c}\text { Latitude } \\
(\mathrm{m} \mathrm{dpl})\end{array}$ & $\begin{array}{c}\text { Tanggal } \\
\text { Isolasi }\end{array}$ & Kolektor \\
\hline Vd-6 & Vanda & $\begin{array}{c}\text { Lembang-Bandung } \\
\text { (Jawa Barat) }\end{array}$ & 1.250 & $08-08-2008$ & Hanudin et al. \\
Ph-7 & Phalaenopsis & $\begin{array}{c}\text { Se gunung-Cianjur } \\
\text { (Jawa Barat) }\end{array}$ & 1.100 & $09-09-2008$ & Hanudin et al. \\
Cipanas-Cianjur \\
Ph-18 & Phalaenopsis & 1.100 & $09-09-2008$ & Hanudin et al. \\
\hline
\end{tabular}
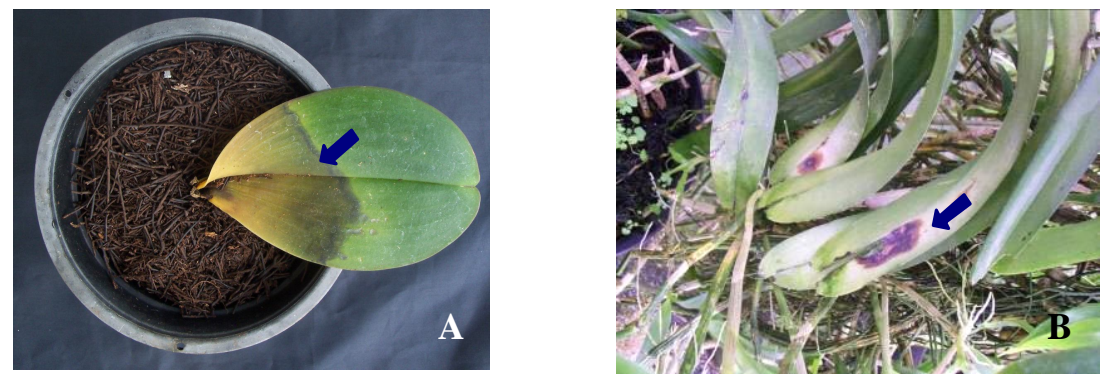

Gambar 2. Karakteristik gejala serangan P. viridiflava pada daun anggrek. (A) Phalaenopsis, (B) Vanda, (tanda panah). 
Tabel 2. Virulensi tiga isolat bakteri PBL yang diduga $P$. viridiflava terhadap anggrek Phalaenopsis dan V anda

\begin{tabular}{ccc}
\hline \multirow{2}{*}{ No. Isolat } & \multicolumn{2}{c}{ Klon Anggrek yang Diuji* } \\
\cline { 2 - 3 } & Phalaenopsis & Vanda \\
\hline Vd-6 & $\mathrm{T}^{* *}$ & $\mathrm{~T}$ \\
Ph-7 & $\mathrm{T}$ & $\mathrm{T}$ \\
Ph-18 & $\mathrm{T}$ & $\mathrm{M}$ \\
\hline
\end{tabular}

* = Dihitung berdasarkan nilai rataan intensitas serangan dari 5 tanaman, pada pengamatan 5 hari setelah inokulasi.

** = Kriteria virulensi ditentukan berdasarkan data intensitas serangan yang dihitung sebagai berikut

$\mathrm{T}=$ Tinggi (Pembusukan mencapai $=60 \%$ dari luas daun yang dinokulasi), $\mathrm{M}=$ medium (Pembusukan mencapai $30-59 \%$ dari luas daun yang dinokulasi, $\mathrm{R}=$ rendah (Pembusukan mencapai $=29 \%$ dari luas daun yang dinokulasi).

Table 3. Karakteristik isolat yang diduga $P$. viridiflava berdasarkan pengujian morfologi, biokimia, dan LOPAT

\begin{tabular}{|c|c|c|}
\hline \multirow[b]{2}{*}{ Jenis Pengujian } & \multicolumn{2}{|c|}{ Klon Tanaman Anggrek } \\
\hline & $\begin{array}{l}\text { Phalaenopsis, } 2 \text { isolat } \\
\quad(\mathrm{Ph}-7 \text { dan } \mathrm{Ph}-18)\end{array}$ & $\begin{array}{l}\text { Vanda, } 1 \text { isolat } \\
(\text { Vd-6) }\end{array}$ \\
\hline \multicolumn{3}{|l|}{ Morfologi } \\
\hline $\begin{array}{l}\text { 1. Bentuk sel } \\
\text { 2. Elevasi } \\
\text { 3. Tepian } \\
\text { 4. Gram }(\mathrm{KOH} 3 \%)\end{array}$ & $\begin{array}{c}\text { Batang } \\
\text { Datar } \\
\text { Bulat/bergelombang } \\
-\end{array}$ & $\begin{array}{c}\text { Batang } \\
\text { Datar } \\
\text { Bulat/bergelombang } \\
-\end{array}$ \\
\hline \multicolumn{3}{|l|}{ Biokimia } \\
\hline $\begin{array}{l}\text { 1. Warna koloni pada media NA } \\
\text { 2. Warna koloni pada media King's B }\end{array}$ & $\begin{array}{c}\text { Krem } \\
\text { Hijau berpendar }\end{array}$ & $\begin{array}{c}\text { Krem } \\
\text { Hijau berpendar }\end{array}$ \\
\hline $\begin{array}{l}\text { 3. Pertumbuhan pada suhu ting gi }\left(34-37{ }^{\circ} \mathrm{C}\right) \\
\text { 4. Pertumbuahn pada kondisi ekstrim }(5 \% \\
\mathrm{NaCl})\end{array}$ & $\begin{array}{l}+ \\
+\end{array}$ & $\begin{array}{l}+ \\
+\end{array}$ \\
\hline $\begin{array}{l}\text { 5. Sensitivitas terhadap antibiotik } \\
\text { erithromisin }\end{array}$ & - & - \\
\hline \multicolumn{3}{|l|}{ Uji LOPAT } \\
\hline 1. Produksi Levan & - & - \\
\hline 2. Reaksi Oxidase & - & - \\
\hline 3. Degradasi Pektin pada kentang & + & + \\
\hline 4. Reaksi Argynine dihydrolase & - & - \\
\hline $\begin{array}{l}\text { 5. Reaksi Hypersensitivitas pada daun } \\
\text { tembakau }\end{array}$ & + & + \\
\hline
\end{tabular}

acid (Nam) yang terikat dalam susunan B, 1-4 (Dube, 1979). Kompleks mukopeptide sering disebut dengan nama murein (Levy et al., 1973).

Hasil pengujian secara biokimia (dibiakkan pada media King's B) terhadap tiga isolat bakteri (Vd-6, Ph7, dan Ph-18), semua isolat yang diuji menunjukkan warna koloni hijau berpendar (fluorescens). Hal ini disebabkan oleh "Pyoverdins" yaitu zat pengkelat besi yang diproduksi oleh suatu bakteri yang tumbuh pada media yang miskin ion besi (King et al., 1954). Sejalan dengan hal tersebut, Godfrey \& Marshall (2002) melaporkan bahwa salah satu spesies bakteri dari genus Pseudomonas yang menyebabkan PBL yaitu $P$. viridiflava. 
Hasil pengamatan pertumbuhan isolat yang diduga $P$. viridiflava pada suhu ekstrim dan uji sensitivitas terhadap antibiotik menunjukkan bahwa semua isolat bakteri yang diuji masing-masing dapat tumbuh dengan baik pada suhu $34-37^{\circ} \mathrm{C}$ dan resisten terhadap antibiotik eritromisin. Di samping itu, ketiga isolat tersebut mampu mendegradasi pektin yang berasal dari umbi kentang dan bereaksi positif terhadap uji hipersensitivitas pada daun tembakau (Tabel 3). Berdasarkan hasil identifikasi tersebut, isolat $\mathrm{Vd}-6, \mathrm{Ph}-7$, dan $\mathrm{Ph}-18$ disimpulkan sebagai $P$. viridiflava.

Evaluasi Resistensi Klon Phalaenopsis terhadap P. viridiflava. Pada pengamatan hari ke 2 setelah inokulasi, semua individu populasi klon F1 Phalaenopsis VL, M22, dan 599 telah terinfeksi PBL dengan intensitas serangan berkisar antara $0,35-81,62 \%$. Hal ini berarti bahwa waktu inkubasi $P$. viridiflva pada semua klon tersebut adalah dua hari.

Pada pengamatan hari ke 3 sampai dengan ke 5 setelah inokulasi, tampak bahwa empat klon VL Phalaenopsis (nomor asesi 231, 232, 233, dan 240); dua klon M22 (nomor asesi 213, dan M22.223); serta empat klon 599 (nomor asesi 201, 205, 215, dan 243) menunjukkan reaksi resisten terhadap $P$. viridiflava. Hal tersebut ditunjukkan oleh intensitas penyakit yang paling rendah yaitu $0,35 \%$ (Tabel 4). Bahkan intensitas serangan PBL pada 10 klon anggrek tersebut tidak berkembang hingga 60 hari dan luka bekas infeksi berubah menjadi kering. Hal ini diduga pada tanaman yang resisten mengandung senyawa kimia yang dapat membunuh patogen.
Sehubungan dengan hal tersebut Mahfud et al. (1997) melaporkan bahwa resistensi tanaman terhadap penyakit dapat berbentuk resistensi kimiawi dan morfologis. Resistensi kimiawi ditunjukkan oleh kemampuan tanaman dalam menghambat infeksi patogen untuk mempertahankan diri menggunakan hasil metabolismenya berupa toksin atau fitoalexin. Afek \& Sztejnberg (1988) melaporkan bahwa fitoaleksin mampu menghambat pertumbuhan dan perkembangan patogen seperti Phytopthora citrophthora pada jeruk.

Pada resistensi morfologis, yang berperan menghambat penetrasi patogen ke dalam jaringan tanaman diantaranya ialah lapisan epidermis. Lapisan epidermis yang lebih tebal dilaporkan dapat menghambat infeksi penyakit bercak hitam pada mawar (Suhardi \& Winarto 2002), penyakit embun tepung pada tanaman jeruk (Mahfud 1991), dan penyakit antraknosa pada tanaman mangga (Mahfud et al. 1993).

\section{SIMPULAN}

Berdasarkan hasil eksplorasi, isolasi pada media King's B dan uji degradasi pektat pada umbi kentang diperoleh tujuh isolat yang diduga PBL. Dari tujuh isolat tersebut tiga isolat (Vd-6, Ph-7, dan Ph-18) diidentifikasi sebagai $P$. viridiflava. Hasil pengujian secara morfologi, biokimia, dan LOPAT menunjukkan bahwa karakteristik patogen tersebut berbentuk batang dengan elevasi permukaan koloni datar, tepian margin rata/ bergelombang, gram negatif, berpendar pada media KB, bereaksi positif terhadap uji pektat dan hipersensitivitas terhadap daun tembakau.

Tabel 4. Frekuensi intensitas serangan PBL dan kriteria resistensi pada individu populasi F1 VL, M22, dan 599 pengamatan hari ke 2 sampai dengan ke 5 setelah inokulasi

\begin{tabular}{|c|c|c|c|c|c|c|c|c|c|c|c|c|c|c|}
\hline \multirow{3}{*}{$\begin{array}{c}\text { Skoring } \\
\text { IS } \\
\text { PBL }(\%)\end{array}$} & \multicolumn{12}{|c|}{$\begin{array}{c}\text { Individu Populasi (F1) Phalaenopsis yang diuji resistensinya } \\
\text { terhadap PBL }\end{array}$} & \multicolumn{2}{|c|}{$\begin{array}{l}\text { Respon tanaman terhadap } \\
\text { P. viridiflava }\end{array}$} \\
\hline & \multicolumn{4}{|c|}{ VL } & \multicolumn{4}{|c|}{ M22 } & \multicolumn{4}{|c|}{599} & \multirow{2}{*}{ Frekuensi } & \multirow{2}{*}{$\begin{array}{l}\text { Kriteria } \\
\text { resistensi }\end{array}$} \\
\hline & 2 & 3 & 4 & 5 & 2 & 3 & 4 & 5 & 2 & 3 & 4 & 5 & & \\
\hline $0.35-10$ & 11 & 9 & 6 & 4 & 19 & 4 & 2 & 2 & 6 & 5 & 5 & 4 & 10 & Resisten \\
\hline $11-40$ & 11 & 3 & 2 & 1 & 16 & 14 & 2 & 0 & 12 & 2 & 0 & 1 & 2 & Rentan \\
\hline $41-60$ & 19 & 13 & 5 & 2 & 5 & 13 & 8 & 3 & 18 & 14 & 2 & 0 & 5 & Rentan \\
\hline $61-80$ & 3 & 14 & 21 & 14 & 3 & 6 & 10 & 9 & 7 & 15 & 20 & 6 & 29 & Sangat rentan \\
\hline $81-100$ & 1 & 6 & 11 & 24 & 1 & 8 & 23 & 31 & 2 & 9 & 18 & 34 & 89 & Sangat rentan \\
\hline Jumlah & 45 & 45 & 45 & 45 & 45 & 45 & 45 & 45 & 45 & 45 & 45 & 45 & 135 & \\
\hline $\begin{array}{l}\text { Klon } \\
\text { resisten }\end{array}$ & $\begin{array}{l}\text { VL } \\
\text { VL } \\
240\end{array}$ & $\begin{array}{l}231, \\
233\end{array}$ & $\begin{array}{ll}\mathrm{VL} \\
\operatorname{lan}\end{array}$ & & $\begin{array}{l}\text { M } 2 \\
\text { M } 2\end{array}$ & .213 & & & $\begin{array}{l}599 \\
205 \\
\text { dan }\end{array}$ & 59 & $\begin{array}{c}599 \\
215 \\
243\end{array}$ & & & \\
\hline
\end{tabular}


Karakteristik gejala serangan $P$. viridiflava pada anggrek phalaenopsis, berupa bercak luka hijau kekuningan pada daun, kemudian luka tersebut berkembang dengan sangat cepat hingga menyebabkan pembusukan jaringan. Sepuluh klon individu populasi F1 anggrek Phalaenopsis VL 231, VL 232, VL 233 dan VL 240; M22.213 dan M22.223; 599.201, 599.205, 599.215 dan 599.243 dinyatakan resisten terhadap P. viridiflava.

\section{SANWACANA}

Penulis mengucapkan terima kasih dan penghargaan yang setinggi-tingginya kepada Kepala Badan Penelitian dan Pengembangan Pertanian, melalui Kepala Pusat Penelitian dan Pengembangan Hortikultura, dan Kepala Balai Penelitian Tanaman Hias yang telah membiayai, memberikan saran, kritik dalam perencanaan dan pelaksanaan penelitian. Penulis mengucapkan terima kasih juga kepada Dr. Tri Joko M.Sc. dari Laboratorium Kesehatan Tanaman, Fakultas Pertanian Universitas Gadjah Mada Yogyakarta yang telah mengamati bentuk sel dan menguji secara Polymerase Chain Reaction bakteri PBL. Ucapan terima kasih juga disampaikan kepada Endang Sutarya, Ridwan Daelani, Dede Surachman, Muhidin, Dadang Kusnandar, Ade Sulaeman, Iskandar Sanusie, M. Irman Firmansyah, Arlan Hernawan, Asep Samsudin dan semua pihak yang telah membantu terlaksananya penelitian ini.

\section{DAFTAR PUSTAKA}

Afek U \& Sztejnberg A. 1988. Accumulation of scoparone, a phytoalexin associated with resistance of citrus to Phytopthora citropthora. Phytopathol. 78(12):1678-1682.

Ayasan Y, Mirik M, Ala A, Sahin F \& Cinar O. 2003. First report of Pseudomonas viridiflava on melon in Turkey. BSPP New Disease Reports (2003)7, 22.

Barras F, Van Gijsegem F \& Chatterjee AK. 1994. Extracellular enzymes and pathogenesis of softrot Erwinia. Annu Rev Phytopathol 32:201"234.

Cating RA \& Palmateer AJ. 2011. Bacterial soft rot of Oncidium Orchids caused by a Dickeya sp. (Pectobacterium chrysanthemi) in Florida. APSnet. Plant Disease 95(1):74.1-74.1.

Chia H L, JLu JC, Prasad V, Hsiao HH, Lee SJ, Yang NS, Huang HE, Feng TY \& Chan WH. 2003. The sweet pepper ferredoxin-like protein (pflp) conferred resistant against soft rot disease in
Oncidium orchid. Transgenic Research 12(3):329-336.

Dube HC. 1979. A Textbook of Fungi, Bacteria, and Viruses. Reprint. Vikas Pub. House PVT. Ltd, New Delhi. 673p.

Godfrey SAC \& Marshall JW. 2002. Identification of cold-tolerant Pseudomonas viridiflava and $P$. marginalis causing severe carrot postharvest bacterial soft rot during refrigerated export from New Zealand. Plant Pathology 51(2):155-162.

Goumans DE \& Chatzaki AK. 1998. Characterization and host range evaluation of Pseudomonas viridiflava from melon, blite, tomato, chrysanthemum and eggplant. European Journal of Plant Pathology 104:181-188.

Gonzales AJ, Rodicio MR, \& Mendoza MC. 2003. Identification of an emergent and atypical Pseudomonas viridiflava lineage causing bacteriosis in plants of agronomic importance in a Spanish Region. Appl Environ Microbiol. 69(5):2936-2941.

Handayati W, Hanudin \& Soedjono S. 2004. Resistensi genotip anggrek Phalaenosis terhadap penyakit busuk lunak. J. Hort. 14 (edisi khusus): 398-402.

Hanudin. 1990. Efektivitas streptomisin sulfat dan oksitetrasiklin 15/1,5 WP terhadap Pseudomonas solanacearum E. F. Smith secara in-vitro. Buletin Penelitian Hortikultura 14(4):18-22.

Hanudin \& Suhardi. 2002. Studi ekobiologi busuk lunak pada anggrek dan pengendaliannya. Laporan Hasil Penelitian Balai Penelitian Tanaman hias. Jakarta. 5 p.

Hanudin \& Suhardi. 2009. Praevaluasi karakter ketahanan terhadap penyakit busuk lunak pada anggrek phalaenopsis. Laporan Hasil Penelitian Balai Penelitian Tanaman Hias TA 2008 Segunung. $14 \mathrm{p}$.

Hanudin, Nuryani W, Budiarto K, Nawangsih AA, \& Tjahjono B. 2011. Identification of soft rot bacterial disease on orchids collected from West Java and DKI Jakarta. Journal of an International Society for Southeast Asian Agricultural Science (in press).

Joko T, Hanudin \& Subandiyah S. 2010. Karakterisasi biologi dan molekular bakteri penyakit busuk lunak pada anggrek untuk mendukung pengembangan deteksi dini dan perakitan tanaman tahan melalui 
introduksi bakteri endo-simbion. Laporan Hasil Penelitian KKP3T TA 2009.

King ED, Ward MK \& Raney DE. 1954. Two simple media for the demonstrations of pyocyanin and fluorescein. Laboratory of Clinical Medication. 44: 301-307.

Lelliott RA \& Stead DE. 1987. Methods for the Diagnosis of Bacterial Diseases of Plants. British. Soc. For Plant. Pathol. Black Well. Scientific Publication. London.

Levy J, Campbell JJR \& Blackburn TH. 1973. Introductory Microbiology. John Willey \& Sons. Inch. New York.

Mahfud MC. 1991. Ketahanan beberapa jenis jeruk terhadap penyakit embun tepung. J. Hort. 1(2):5457.

Mahfud MC, Hermanto C, Prahardini PER \& Rachmawati D. 1993. Ketahanan beberapa jenis mangga terhadap penyakit antraknos. Penel. Hort. 5(3):52-56.

Mahfud MC, Purnomo S, Handoko, Tegopati B \& Sugiyarto M. 1997. Perbedaan ketahanan beberapa jenis mangga terhadap penyakit antraknosa. J. Hort. 7(1):561-565.
Price T, Hanudin \& Reza R. 1999. Bacteriology, CAQ short course-Practical Requirements. Integrated Pest Management for Smallholder Estate Crops Project- Plant Quarantine Component, 72p.

Samson R, Legendre JB, Christen R, Fischer-Le Saux M, Achouak W \& Gardan L. 2005. Transfer of Pectobacterium chrysanthemi (Burkholder et al. 1953) Brenner et al. 1973 and Brenneria paradisiaca to the genus Dickeya gen. nov. as Dickeya chrysanthemi comb. nov. and Dickeya paradisiaca comb. nov. and delineation of four novel species, Dickeya dadantii sp. nov., Dickeya dianthicola sp. nov., Dickeya dieffenbachia sp. nov., and Dickeya zeae sp. nov. International Journal of Systematic Evolution Microbiology. 55: 1415"1427.

Schaad NW, Jones JB \& Chun W. 2001. Laboratory Guide for Identification of Plant Pathogenic Bacteria. APS Press USA. 373 p.

Suhardi \& Winarto B. 2002. Resistensi varietas mawar (Rosa hybrida) terhadap penyakit bercak hitam. J. Hort. 12(1): 56-63.

Suslow TV, Scorth NN \& Isaka M. 1982. Application of rapid methods for gram differentiation of plant pathogenic and saprophytic bacteria without staining. Phytopathology. 72: 917 - 918. 